\title{
Исследование видового разнообразия грибов-литобионтов, выделенны с образцов цементных композитов, содержащих известняки различного происхождения и подвергнутых старению в условиях черноморского климата
}

\author{
В.Т.Ерофеев, МГУ им. Н.П. Огарёва, Саранск \\ Е.Н.Каблов, ВИАМ, Москва \\ О.В.Старцев, ВИАМ, Москва \\ В.Ф.Смирнов, ННГУ им. Н.И. Лобачевского, Нижний Новгород \\ И.В.Ерофеева, НИИСФ РААСН, Москва \\ B.В.Ушкина, Республиканский лицей для одаренных детей, Саранск \\ Д.В.Емельянов, МГУ им. Н.П. Огарёва, Саранск \\ Э.М.Балатханова, ГГНТУ им. акад. М.Д. Миллионщикова, Грозный \\ С.А.Коротаев, МГУ им. Н.П. Огарёва, Саранск
}

В статье приводятся результаты исследования биостойкости цементных композитов, наполненных карбонатными и силикатными породами, экспонируемых в течение одного года в условиях черноморского климата на открытой площадке и под навесом, а также в морской воде. Определено видовое и родовое разнообразие грибов-литобионтов, заселяющих образцы, обусловленное происхождением карбонатной породы и условиями старения. По результатам исследований установлено, что биологическое обрастание, количество видов в сообществе, а также конкретный видовой состав в большей мере зависят от условий эксплуатации материала, нежели от минерального состава наполнителя. В работе дана классификация биологических агентов - разрушителей строительных материалов - в зависимости от оптимальных условий для их роста, что может быть перспективно для дальнейшей разработки подходов для борьбы с ними. Установлены рациональные составы цементных композитов, полученных на основе известняков различного происхождения.

Ключевые слова: цементные композиты, наполнитель, известняк, доломит, кварцевый песок, микромицеты, грибылитобионты, биостойкость, долговечность.

The Study of Species Diversity of Fungi-Litaliano Allocated with Samples of Cement Composites Containing Limestones of Different Origin and Subjected to Aging at Conditions of the Black Sea Climate

V.T.Erofeev, Ogarev Mordovia State University, Saransk

E.N.Kablov, VIAM, Moscow

0.V.Startsev, VIAM, Moscow

V.F.Smirnov, UNN, Nizhniy Novgorod

I.V.Erofeeva, NIISF RAASN, Moscow
V.V.Ushkina, Republican Lyceum for Gifted Children, Saransk D.V.Emelyanov, Ogarev Mordovia State University, Saransk Je.M.Balathanova, Millionshikov Grozny State Oil Technical University, Grozny

S.A.Korotaev, Ogarev Mordovia State University, Saransk

The article presents the results of a study of the decay resistance of cement composites filled with carbonate and silicate rocks. The investigated composites exhibited for one year under conditions of the black sea climate in the open air under a canopy of sea coast and sea water. Species and generic diversity of fungi-Litvinov on the samples, depending on the origin of carbonate rocks and the conditions of aging. By results of researches it is stated that fouling, the number of species in the community, as well as specific species composition to a greater extent depends on the operating conditions of the material, and to a lesser extent on the mineral composition of the filler. The authors give a classification of biological agentsdestructors of building materials in their preferred conditions of growth that may be promising for the further development of approaches to deal with them. Installed rational compositions of concrete composites derived from limestones of different origin.

Keywords: cement composites, filler,limestone, dolomite, quartz sand, micromycetes, fungi-lithobiont, biostability, durability.

Физико-механические и другие свойства цементных композитов в значительной степени определяются наполнителями и заполнителями различной крупности. При создании материалов нового поколения важная роль отводится, наряду с пластифицирующими добавками, микронаполнителям [1-6]. В качестве микронаполнителей в цементных композитах раз- 
личного назначения используют отходы производства ферросилиция, доменные шлаки и золы, подвергнутые измельчению кремнезём, диатомит и другие вещества [7-10]. Эффекты, к которым приводит введение перечисленных веществ в состав бетонов, обусловлены несколькими известными механизмами действия, а именно: пуццолановой активностью, характерной для микронаполнителей, содержащих в составе диоксид кремния; микронаполняющим эффектом, позволяющим уменьшить пористость материала (положительное влияние на прочностные характеристики материалов проявляется лишь до некоторого предела введения микронаполнителя), при котором микронаполнитель не образует контактов между собственными частицами и не препятствует росту новообразований в процессе схватывания и твердения цементного камня; эффектом нуклеации и ускорения начала твердения (в этом случае тонкодисперсные частицы выступают в роли центров кристаллизации новообразований) [11-13].

При избытке наполнителя с высокой дисперсностью зёрен возникают участки самонапряжения, что, по мере роста кристаллов, может привести к образованию трещин и другим нарушениям однородности микроструктуры. Для снятия таких деструктивных напряжений необходимо включение в состав наполнителя частиц бо́льших размеров, при котором возможно образование эпитаксиальных контактов нового типа, основанных на силах электростатического притяжения и механического защемления.

Все перечисленные эффекты способствуют формированию более упорядоченной структуры материала, характеризующейся уменьшением объёма межчастичных пустот, повышением капиллярного потенциала и увеличением прочности и энергии связи между частицами цемента и заполнителя [14-16].

Устойчивость композитов к биологической коррозии зависит от многих факторов: наличия биоцидных и гидрофобизирующих добавок, структуры материала и его пористости, наличия защитных пропиток и покрытий, условий эксплуатации и т.д. [17-25].

К наиболее доступным заполнителям для бетонов относятся осадочные породы, а именно известняки. Последние не

Таблица 1. Матрица планирования и рабочая матрица эксперимента

\begin{tabular}{|c|c|c|c|c|c|c|}
\hline \multirow[b]{2}{*}{$\begin{array}{c}\text { W } \\
\text { onturs }\end{array}$} & \multicolumn{3}{|c|}{ 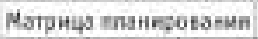 } & \multicolumn{3}{|c|}{ Pa6ovas мaтpeus } \\
\hline & $x t$ & $x 2$ & $x 3$ & 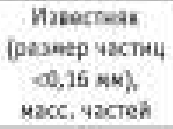 & 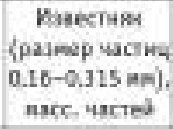 & $\begin{array}{c}\text { Kaapseawh ne- } \\
\text { cas (e0,325- } \\
0,63 \text { kn), wace. } \\
\text { 4acted }\end{array}$ \\
\hline 1 & 1 & 0 & 0 & 1 & 6 & 6 \\
\hline 2 & $\theta$ & 1 & 0 & 0 & 1 & 8 \\
\hline 3 & 0 & 0 & 1 & 0 & 6 & 1 \\
\hline 4 & $1 / 3$ & $2 / 3$ & 0 & Q.33 & 0,07 & $\theta$ \\
\hline 5 & $1 / 3$ & 0 & $2 / 3$ & 0.33 & $\theta$ & 0.63 \\
\hline 6 & 0 & $1 / 3$ & $\varepsilon / 3$ & 0 & a.s3 & 067 \\
\hline 3 & $2 / 3$ & $1 / 3$ & 0 & 0,67 & 0,33 & $\theta$ \\
\hline B. & $2 / 3$ & $a$ & $1 / 3$ & 067 & c) & 0.33 \\
\hline D. & 0. & $2 / 3$ & $1 / 3$ & 0. & 0.57 & 0,33 \\
\hline 10 & $1 / 3$ & $1 / 3$ & $1 / 3$ & 0,99 & 0,33 & 0,33 \\
\hline
\end{tabular}

являются полностью инертными материалами и вступают во взаимодействие с гидратными фазами минералов клинкера, однако в отличие от кремнезёмистых наполнителей, они не приводят к образованию фаз высокой прочности, поэтому использование при получении материалов с высокими показателями прочности и долговечности в качестве заполнителя только известняка нецелесообразно. С другой стороны, введение тонкодисперсных добавок карбоната кальция, обладающих высокой поверхностной энергией частиц, может способствовать увеличению числа центров кристаллизации, уплотнению структуры материала и уменьшению объёма капиллярных пор.

Чем лучшей структурой характеризуется материал, тем сложнее биологическим организмам (бактериям и грибам) адаптироваться к существованию на его поверхности, тем большее время им необходимо для её заселения и приспособления к своему существованию. Последнее выражается в формировании микротрещин, повышении гидрофильности поверхности и, как результат, разрушении материала. Микроорганизм на поверхности может как образовывать активнорастущие колонии, так и находиться в покоящемся состоянии спор. Способность микроорганизма разрушать композиты обусловлена целым комплексом его биохимических свойств. Как правило, наиболее агрессивными деструкторами материалов выступают микроорганизмы, способные образовывать органические кислоты и ферменты, а также экзополи сахариды, сорбирующие воду, органические кислоты и продукты взаимодействия кислот с компонентами цементного камня. Не меньшую роль играет физическое разрушение субстрата, которое осуществляют грибные культуры за счёт развития проникающих в микротрещины гиф.

Целью исследования стало изучение возможности повышения биостойкости материалов за счёт подбора гранулометрического состава наполнителей и соотношения карбонатных и силикатных пород. В качестве наполнителя использовали кварцевый песок и известняки из трёх природных источников. Старение образцов происходило в течение одного года в условиях черноморского климата на открытой площадке и под навесом, а также в морской воде.

Для достижения этой цели были поставлены следующие задачи.

1. Оценить видовое и родовое разнообразие микромицетов, заселяющих образцы, экспонировавшиеся в течение одного года в условиях черноморского климата.

2. Оценить видовое и родовое разнообразие грибов-литобионтов в зависимости от происхождения карбонатной породы и условий старения, а также степень сходства групп.

3. Определить оптимальные составы цементных композитов, полученных на основе известняков разного происхождения.

4. Сделать вывод о влиянии природы и дисперсности наполнителя, а также соотношения фракций на биологическое обрастание материала.

Исследования были проведены с применением методов математического планирования эксперимента (симплекс- 
решетчатого плана Шеффе). Для выполнения эксперимента была использована трёхфакторная матрица в виде плана, состоящего из десяти опытов. Для проведения исследования были подготовлены образцы цементных композитов. Исследуемые составы включали портландцемент 500-Д0 производства ГУП «Чеченцемент» (н.п. Чири-Юрт), кварцевый порошок (месторождение расположено на реке Терек в 20-ти километрах к северу от города Грозного) и карбонатные порошки разной дисперсности (месторождения расположены вблизи города Грозного). Соотношение портландцемента и смеси наполнителей было принято 1:1. Матрица планирования и рабочая матрица приведены в таблице 1.

На образцах материалов были обнаружены 44 различные культуры микромицетов. 22,7 \% всех видов были выделены одновременно в трёх условиях старения. Видовой состав грибов отражён в таблице 2. В этой же таблице приведён сравнительный анализ видового разнообразия.

Исходя из полученных данных можно охарактеризовать сообщество микромицетов, способных к заселению на образцы цементных композитов. Все выделенные культуры относятся к 12-ти родам грибов. К видам-доминантам можно отнести Alternariabrassicae и Fusariummoniliforme. Большая часть видов была условно отнесена к очень редким, их встречаемость составляет меньше $2 \%$, а суммарно на них приходится 59,1 \% всего видового разнообразия.

Полученные результаты свидетельствуют, что различия между сообществами микромицетов, заселивших цементные композиты на основе известняков, различающихся по происхождению, невелики. 17 видов грибов заселяют композиты на основе известняков вне зависимости от природы последних. Результаты попарного сравнения сообществ микромицетов приведены в таблице 3. Для оценки бинарного сходства использовали коэффициент Серенсена [26].

Анализ полученных данных показал, что 12 видов микромицетов оказались безразличны к факторам окружающей среды и заселили образцы цементных композитов вне зависимости от них. Попарное сравнение показало, что наибольшими различиями характеризуются сообщества грибов, заселивших материалы, состаренные в морской воде и на открытой площадке.

Встречаемость родов микромицетов на материалах в зависимости от условий окружающей среды приведена на рисунках 1-3.

Таблица 3. Анализ сходства видового разнообразия. Значения коэффициента Сенерсена

\begin{tabular}{|c|c|c|c|}
\hline Ycacens старенка & $\begin{array}{l}\text { fo отр⿰丨丨⿱㇒⿲丶丶㇒木 } \\
\text { nocuacos }\end{array}$ & Поанавесон & $\begin{array}{l}5 \text { mapowa } \\
\text { espe }\end{array}$ \\
\hline 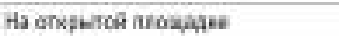 & & 646 & 56.6 \\
\hline fleq rasecuen & & & 67.9 \\
\hline \multicolumn{4}{|l|}{3 мอ } \\
\hline Пponcrosakune Haneateanent & 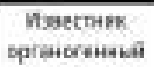 & $\begin{array}{l}\text { Vssectams } \\
\text { peutous }\end{array}$ & $\begin{array}{l}\text { flownit } \\
\text { rapmad }\end{array}$ \\
\hline Assectrm opraseorestud & & 645 & 710 \\
\hline Gatcriogr peutwo & & & 75,4 \\
\hline Danomat roptiel & & & \\
\hline
\end{tabular}

На образцах, содержащих речной известняк, встречаются все 12 родов микромицетов. При использовании доломита их число сокращается до 11, а известняка органического происхождения - до девяти. Число выявленных родов грибов-литобионтов на образцах изменяется и в зависимости от условий старения. На образцах, экспонировавшихся на открытой площадке, не обнаружены Rhizopus и Mucor. При старении в наземно-воздушных условиях под навесом на образцах не встречались грибы родов Stachybotrys и Verticillium. В водных условиях наряду с двумя последними родами также не встречается Chaetomium. Вероятно, этот факт связан с особенностями биологии грибов перечисленных таксономических групп. Особенно следует отметить тот факт, что встречаемость грибов родов Aspergillus и Penicillium возрастает до 20 и 22 \% соответственно при старении материалов в морской воде, что может косвенно свидетельствовать о большей глубине их поражения в этих условиях, так как перечисленные роды относятся к активным деструкторам каменных материалов.

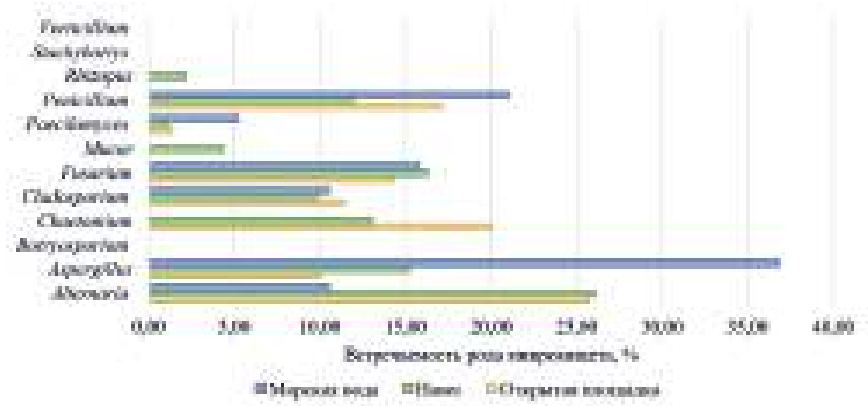

Рис. 1. Встречаемость родов микромицетов при старении образцов на основе органогенного известняка в течение одного года

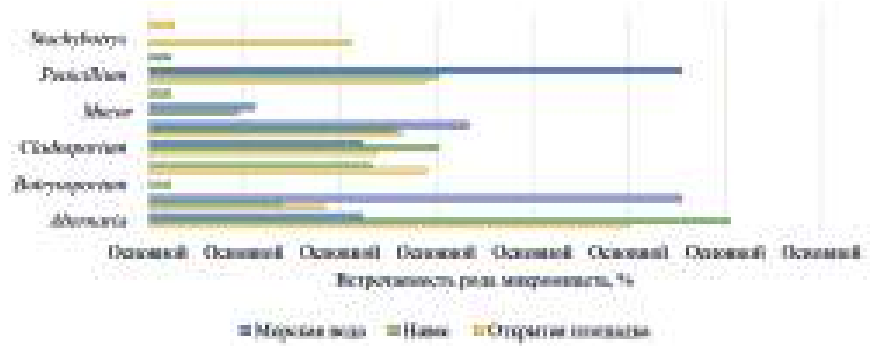

Рис. 2. Встречаемость родов микромицетов при старении образцов на основе известняка речного происхождения в течение одного года

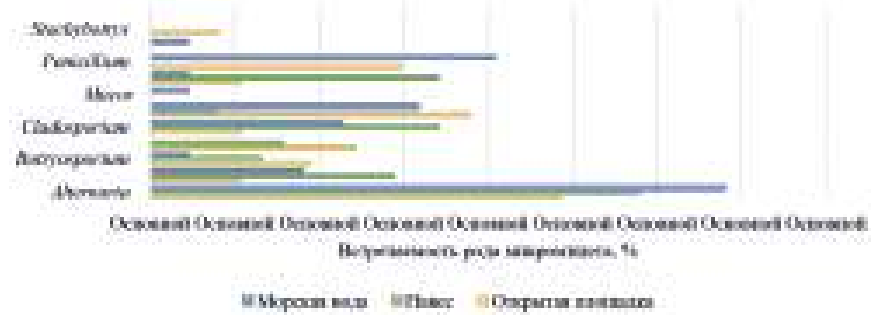

Рис. 3. Встречаемость родов микромицетов при старении образцов на основе доломита горного происхождения в течение одного года 
Таблица 2. Видовой состав грибов-литобионтов, выделенных с образцов цементных композитов

\begin{tabular}{|c|c|c|c|c|c|c|}
\hline \multirow[b]{2}{*}{ Batas semsposerueros } & \multicolumn{3}{|c|}{ 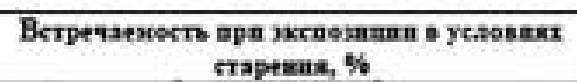 } & \multicolumn{3}{|c|}{ 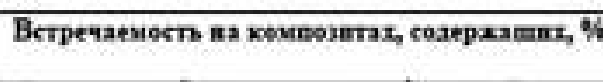 } \\
\hline & $\begin{array}{c}\text { as } \\
\text { orkptroñ } \\
\text { nзomanot }\end{array}$ & $\begin{array}{c}\text { nes } \\
\text { wanecose }\end{array}$ & $\begin{array}{l}\text { stopesool } \\
\text { neat }\end{array}$ & 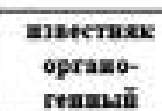 & $\begin{array}{l}\text { moterane } \\
\text { pequoü }\end{array}$ & $\begin{array}{l}\text { gasesart } \\
\text { ropaniĭ }\end{array}$ \\
\hline Altemaria altemata & 2,7 & 4,3 & 3,7 & 3,9 & 1,7 & 5.2 \\
\hline Altemaria brassicae & 13,2 & 11,0 & 13,6 & 11,6 & 12,2 & 12,9 \\
\hline Aitemaria dianthi & 0,5 & - & - & - & - & 0,5 \\
\hline Altemaria dichondrae & 1,8 & - & - & - & 1,1 & 1,0 \\
\hline Altemaria flaared & - & 0.4 & - & - & 0,6 & - \\
\hline Altemaria pluriseptata & 1.4 & 1,2 & 2.5 & 2.8 & - & 1.5 \\
\hline Altemaria solani & 3,6 & 3,9 & 1,2 & 2,2 & 5.6 & 2,6 \\
\hline Altemaria temis & - & 0.4 & - & 0.6 & - & - \\
\hline Altemaria tenuissima & 1.8 & 7.1 & 2,5 & 3.3 & 5.0 & 4,6 \\
\hline Aspergillas clavahes & - & 0,4 & - & - & - & 0,5 \\
\hline Aspergillus favipes & - & 0,4 & - & 0,6 & - & - \\
\hline Aspergilius fumiganus & - & 1,2 & - & 1,1 & - & 0,5 \\
\hline Aspergillus niger & 4,1 & 6,3 & 17,3 & 9,9 & 6,7 & 4,6 \\
\hline Aspergillus oryzae & 3.2 & 3,1 & - & 3,3 & 3,3 & 1,5 \\
\hline Aspergillus sulphureus & - & 0.8 & 2,5 & 0,6 & - & 1,5 \\
\hline Aspergillus terreus & 0,5 & - & - & - & - & 0,5 \\
\hline Aspergillus ustis & 0.5 & - & - & - & - & 0,5 \\
\hline Botryosporium longibrachiatum & 0,9 & - & - & - & - & 1,0 \\
\hline Botrysporium pilulifenum & 2,3 & 1,6 & 1,2 & - & 0,6 & 4,6 \\
\hline Chaetomium dolichortrichum & 12,7 & 6,7 & - & 9,4 & 8,9 & 6,2 \\
\hline Chaetomium globosum & 2.7 & 3,9 & - & 5.0 & 2.8 & 1.0 \\
\hline Cladosporium elathm & 8,6 & 8,3 & 9,9 & 8,8 & 10,0 & 7,2 \\
\hline Cladosporium herbarum & 0,9 & 2.8 & 12 & 1.7 & 3,3 & 0,5 \\
\hline Fusarium avenacesm & 4,1 & 3.5 & - & 3,3 & 2,2 & 4,1 \\
\hline Fusarium javanicam & 0,5 & 0.4 & - & 0.6 & - & 0.5 \\
\hline Fusarium moniliforme & 9,5 & 10,2 & 16.0 & 9,9 & 11,1 & 11,3 \\
\hline Fusarium sambucinum & 1.4 & 1,2 & $\frac{10}{-}$ & 1,7 & - & $\frac{1.5}{1.5}$ \\
\hline Mucor corticola & - & 39 & 2,5 & 2,2 & 2.2 & 2.1 \\
\hline Mucor laxorhizus & - & 0.4 & - & - & 0.6 & - \\
\hline Paecilomyces variotii & 2,3 & 0.8 & 2.5 & 1,7 & 0.6 & 2.6 \\
\hline Penicillinum canescens & - & 0.4 & 1,2 & - & 0, & $\frac{2,0}{1.0}$ \\
\hline Penicillinm chrysogenum & 1.4 & 3,1 & 11.1 & 4,4 & 2.8 & 3.6 \\
\hline Penicillinem cyclopitam & 0,9 & - & 1,2 & - & 1,1 & 0,5 \\
\hline Penicillinum finiculosum & 0,5 & - & - & 0.6 & - & - \\
\hline Penicillinem godlewskil & - & 0.4 & 3,7 & - & 0.6 & 1.5 \\
\hline Penicillinm lanosum & - & - & 1,2 & - & - & 0.5 \\
\hline Penicillinum nigricans & 11.8 & 8.7 & - & 9,4 & 8.9 & 7.7 \\
\hline Penicillinem oxalicrm & - & - & 3.7 & - & 1.1 & 0.5 \\
\hline Penicillhum palitans & 0,9 & - & - & - & 0.6 & 0.5 \\
\hline Penicillhum puberulum & - & 1.6 & - & - & 1,1 & 1.0 \\
\hline Penicillinum purpturogenum & - & 0,4 & - & 0,6 & - & - \\
\hline Rhisopus cohnit & - & 1,2 & 1.2 & 1,1 & 0.6 & 0.5 \\
\hline Stachubotrys chariarum & 5,0 & - & - & - & 4,4 & 1.5 \\
\hline Verticillinum tenernm & 0,5 & - & - & - & 0,6 & - \\
\hline Óupee yucro sudos & 29 & 32 & 20 & 26 & 28 & 37 \\
\hline 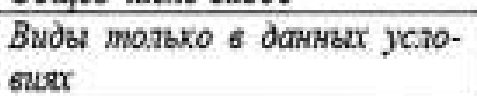 & 9 & 8 & 2 & 4 & 7 & 7 \\
\hline
\end{tabular}


Сравнительный анализ показал, что наименьшая встречаемость пенициллов характерна для композитов на основе известняка органического происхождения, а относительная встречаемость аспергиллов ниже на материалах, содержащих доломит.

Из полученных результатов также следует, что все микромицеты можно разделить на группы в зависимости от их отношения к условиям развития и роста. Анализ образцов, содержащих в качестве микронаполнителя известняки речного, органического и горного происхождения, представляющие собой минерал кальцит и различающиеся составом примесей, показал, что роды грибов можно условно разделить на три группы по отношению к инсоляции: преимущественно произрастающие на свету, преимущественно произрастающие в тени и безразличные к условиям освещения (табл. 4).

Ультрафиолет может играть важную роль в процессах размножения грибов, вызывать возникновение мутаций. Выявление способности к росту в различных условиях важно для ведения рациональной борьбы с биологическим разрушением зданий и сооружений.

На основе проведённого исследования культуры грибов были разделены на три группы в зависимости от того, в каких условиях (водных или наземно-воздушных) они преимущественно встречаются на цементных композитах, содержащих известняки органического, речного и горного происхождения. Результаты данной классификации приведены в таблице 5.

Анализ показал, что максимальное внутриродовое разнообразие видов отмечается на образцах, экспонировавшихся в наземно-воздушных условиях под навесом (рис. 4, 5).

Для оценки влияния природы наполнителя и его гранулометрического состава на биообрастание были определены полиномиальные зависимости и построены поверхности отклика полученных функций. Результаты отражены на рисунках 6-8. Сравнительный анализ показал, что поверхности отклика, полученные в условиях старения в морской воде и под на-

Таблица 4. Отношение грибов - деструкторов искусственного камня, к свету

\begin{tabular}{|c|c|c|}
\hline $\begin{array}{l}\text { Предлочитаiот } \\
\text { свет }\end{array}$ & $\begin{array}{c}\text { Предпомытают } \\
\text { тень }\end{array}$ & $\begin{array}{c}\text { Безразиичны } \\
\text { к условиям осведіения }\end{array}$ \\
\hline $\begin{array}{l}\text { Stachybotrys } \\
\text { Botrysporium } \\
\text { Paecilomyces } \\
\text { Verticillium }\end{array}$ & $\begin{array}{l}\text { Aspergillus } \\
\text { Mucor, } \\
\text { Rhizopus }\end{array}$ & $\begin{array}{c}\text { Alternaria } \\
\text { Cladosporium } \\
\text { Chaetomium } \\
\text { Penicillium } \\
\text { Fusarium }\end{array}$ \\
\hline
\end{tabular}

Таблица 5. Классификация грибов в зависимости от предпочитаемых ими условий

\begin{tabular}{|c|c|c|}
\hline 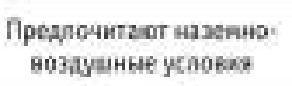 & $\begin{array}{l}\text { Ipeanoveravet } \\
\text { sodinte jenceiss }\end{array}$ & $\begin{array}{l}\text { Безразиянина } \\
\text { п успоамак }\end{array}$ \\
\hline $\begin{array}{l}\text { Ohaetonium } \\
\text { Stachybotrys } \\
\text { Verticilium } \\
\text { Alternaria } \\
\text { Botryosporiun }\end{array}$ & $\begin{array}{l}\text { Aspergillus } \\
\text { Pascilomyces } \\
\text { Rhizopus } \\
\text { Penicillium }\end{array}$ & $\begin{array}{c}\text { Clacosporium } \\
\text { Fusarium } \\
\text { Mucon }\end{array}$ \\
\hline
\end{tabular}

весом, для всех типов заполнителя похожи. Скорее всего, это связано с тем, что для названных условий характерны меньшие перепады значений, исключено воздействие ультрафиолета, более однородные характеристики влажности.

При использовании в качестве наполнителя известняка органического происхождения анализ показал следующее.

1. В условиях экспонирования на открытой площадке при содержании песка от 60 до $100 \%$ от общей массы наполнителя при постоянном количестве известняка с $S_{\text {уд }}=9$ 000-9 200 $\mathrm{cm}^{2} / \Gamma$ увеличение содержания известняка с $S_{\text {уд }}=6000-6200$ $\mathrm{cm}^{2} /$ приводит к снижению видового разнообразия грибного сообщества, также как и спорообразующих единиц, выделенных с поверхности образца. При постоянстве содержания известняка крупной фракции снижение содержания известняка мелкой фракции приводит к снижению числа видов контаминант.

Если процент содержания кварцевого наполнителя при постоянном количестве известняка крупной фракции колеблется (находится в пределах) от 0 до 60, то зависимость числа выделенных культур от содержания известняка мелкой фракции носит характер кривой с максимумом. При постоянном содержании известняка мелкой фракции увеличение количества известняка крупной фракции ведёт к росту числа видов грибов, заселившихся на образцы, кроме случаев, когда количество кварцевого песка в наполнителе находится

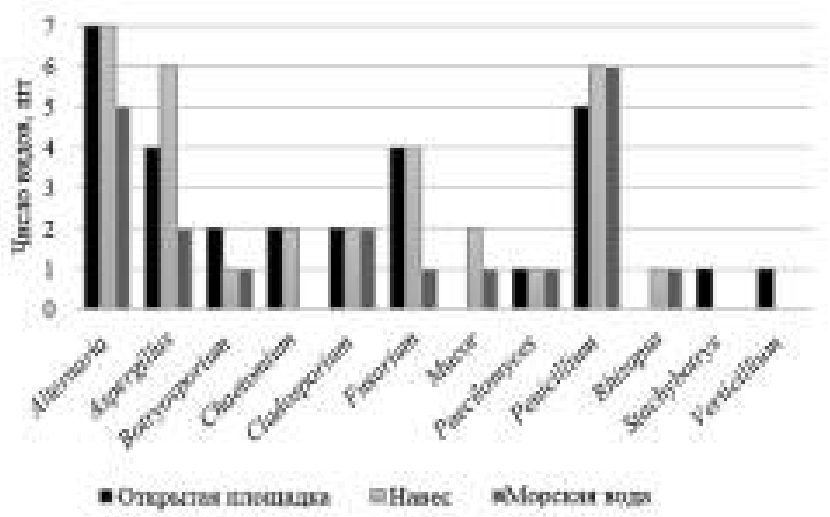

Рис. 4. Изменение видового разнообразия микромицетов в зависимости от условий окружающей среды

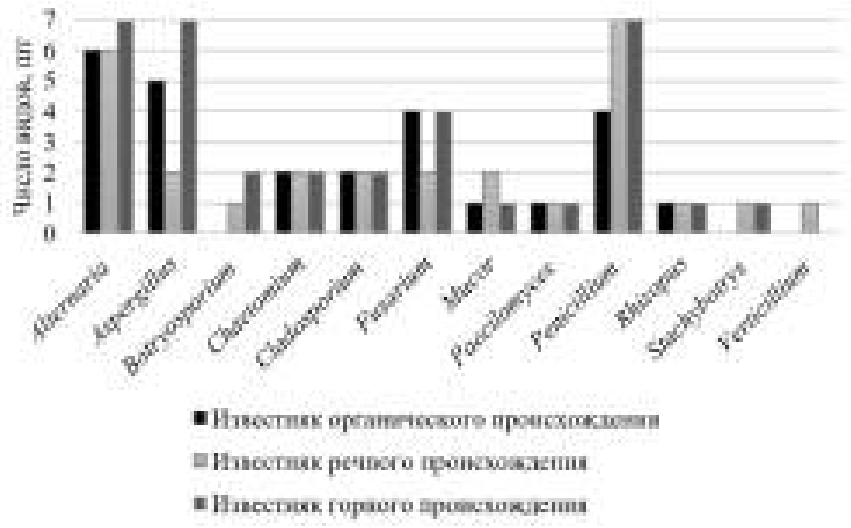

Рис. 5. Изменение видового разнообразия микромицетов в зависимости от природы наполнителя 
в пределах от 90 до $100 \%$. Здесь зависимость носит вид кривой с одним максимумом.

2. Отмечено, что в случае старения в наземно-воздушных условиях под навесом, зависимость количества видов микромицетов от содержания кварцевого наполнителя носит характер кривой с одним максимумом. При низких содержаниях известняка мелкой фракции увеличение количества известняка крупной фракции ведёт к росту контаминации, при высоком же содержании мелкой фракции наполнителя увеличение содержания известняка крупной фракции обусловливает снижение числа видов микроорганизмов.

3. Анализ результатов исследования образцов, экспонировавшихся в морской воде, и сопоставление их с данными по другим средам их старения показал, что наиболее биостойким является состав, включающий 80-100\% известняка
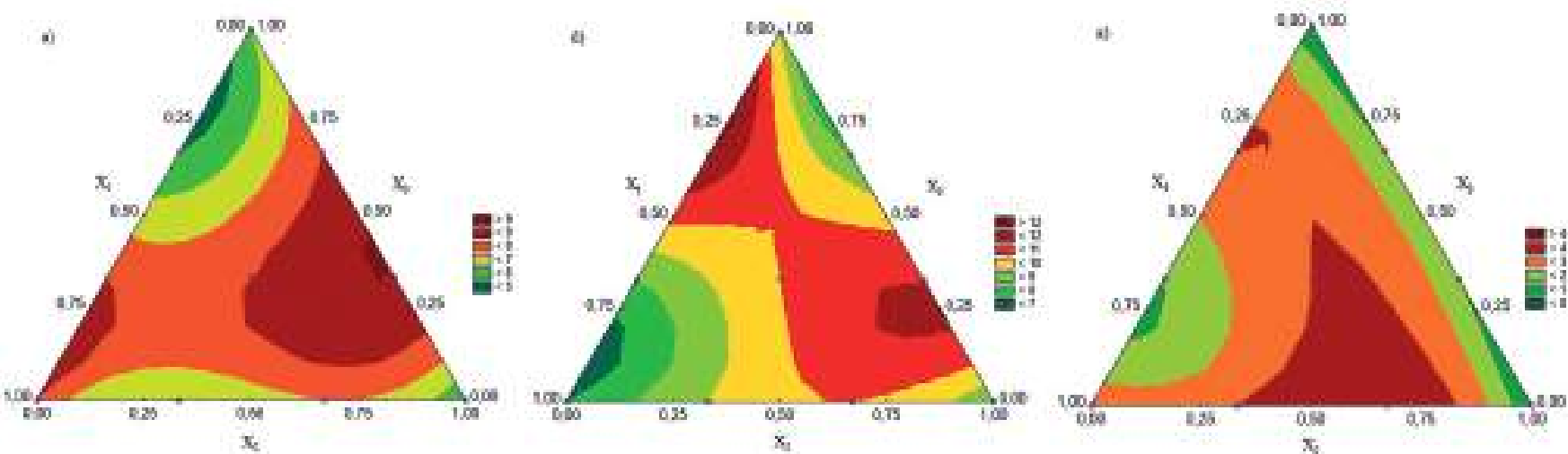

Рис. 6. Зависимость видового разнообразия сообществ микромицетов от гранулометрического состава известняка органического происхождения после старения в течение одного года в условиях: а) наземно-воздушных под открытым небом; б) наземно-воздушных под навесом; в) водных
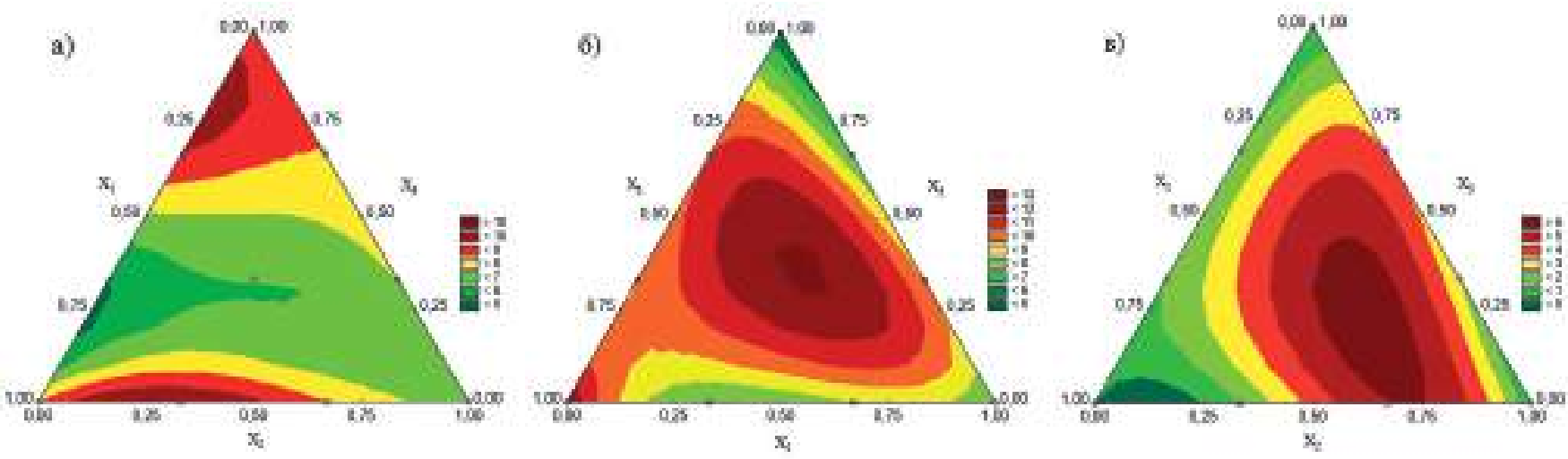

Рис. 7. Зависимость видового разнообразия сообществ микромицетов от гранулометрического состава известняка речного происхождения после старения в течение одного года в условиях: а) наземно-воздушных под открытым небом; б) наземновоздушных под навесом; в) водных
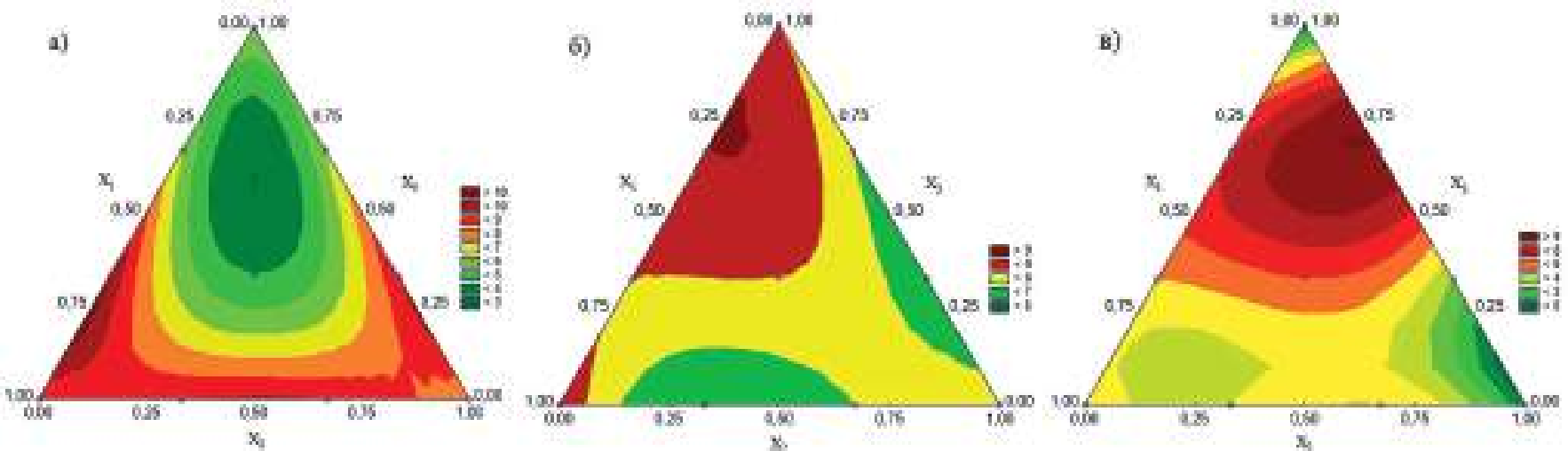

Рис. 8. Зависимость видового разнообразия сообществ микромицетов от гранулометрического состава доломита горного происхождения после старения в течение одного года в условиях: а) наземно-воздушных под открытым небом; б) наземновоздушных под навесом; б) водных 
с $S_{\text {уд }}=9000-9200 \mathrm{~cm}^{2} / \Gamma, 0-20 \%$ известняка с $S_{\text {уд }}=6000-6$ $200 \mathrm{~cm}^{2} / \Gamma, 0-5 \%$ кварцевого песка с $S_{\text {уд }}=3100-3300 \mathrm{~cm}^{2} / \Gamma$.

Аналогичные результаты были получены для известняка речного и доломита горного. Области, соответствующие наиболее биостойким составам, приведены в таблице 6.

Таблица 6. Наиболее биостойкие составы

\begin{tabular}{|c|c|}
\hline Hanomнитеnt & Cocras \\
\hline 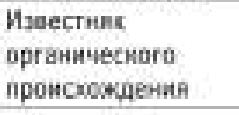 & 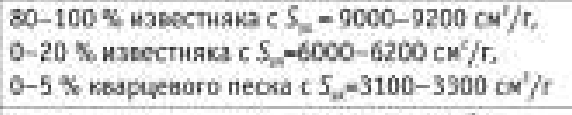 \\
\hline $\begin{array}{l}\text { Изеестнек речного } \\
\text { промсоожльния }\end{array}$ & 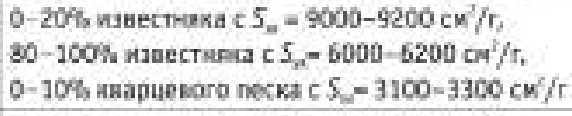 \\
\hline $\begin{array}{l}\text { доломит торного } \\
\text { промсокждения }\end{array}$ & 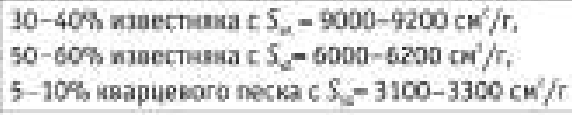 \\
\hline
\end{tabular}

Материалы, приведённые в таблице 6, перспективны для дальнейшего изучения. Из представленных данных следует, что содержание кварцевого песка для всех составов не превышает 10 \% от общего количества наполнителя.

\section{Выводы}

1. Биологическое обрастание, количество видов микромицетов в сообществе, а также конкретный видовой состав в большей мере зависят от условий эксплуатации материала, нежели от минерального состава наполнителя.

2. Сообщества микромицетов, выделенные со строительных материалов, полученных на основе наполнителей различной природы, имеют характерные отличия. В среднем около одной трети видов являются характерными для конкретного вида наполнителя.

3. В работе предпринята попытка классификации биологических агентов - разрушителей строительных материалов, по предпочтительным для них условиям роста, что может быть перспективно в плане дальнейшей разработки подходов для борьбы с ними.

\section{Лuтература}

1. Калашников, В.И. Как превратить бетоны старого поколения в высокоэффективные бетоны нового поколения / В.И. Калашников // Бетон и железобетон. - 2012. - № 1. - С. 82-89.

2. Бобрышев, А.Н. Физика и синергетика дисперсно-неупорядоченных конденсированных композитных систем / А.Н. Бобрышев, В. Т. Ерофеев, В.Н. Козомазов. - СПб. : Наука, 2012. -476 c.

3. Калашников, В.И. Что такое порошково-активированный бетон нового поколения / В.И. Калашников // Строительные материалы. - 2012. - № 10. - С. 70-71.

4. Наногидросиликатные технологии в производстве бетонов / В.И. Калашников, В.Т. Ерофеев, М.Н. Мороз [и др.] // Строительные материалы. - 2014. - № 5. - С. 88-91.

5. Калашников, В.И. Суспензионно-наполненные бетонные смеси для порошково-активированных бетонов нового поколе- ния / В.И. Калашников, В.Т. Ерофеев, О.В. Тараканов // Известия вузов. Серия «Строительство». - 2016. - № 4 (688). - С. 30-37.

6. Калашников, В.И. Высокопрочные бетоны нового поколения / В.И. Калашников, И.В. Ерофеева // Science without borders. - 2016. - Vol. 20. - Р. 82-85.

7. Калашников, В.И. Высокопрочные бетоны нового поколения с низким удельным расходом цемента на единицу прочности / В.И. Калашников, В.М. Володин, И.В. Ерофеева // Vedecky pokrok na prelomu tysyachalety. - 2015. - P. 65-67.

8. Роль дисперсности и качества кварцевого песка на реологию и прочностные свойства суспензионного бетона / С.В. Ананьев, С.В. Аксенов, И.В. Ерофеева, В. И. Калашников // Nauka i inowacja. - 2014. - Vol. 10. - P. 40-44.

9. Каприелов, С.С. Влияние структуры цементного камня с добавками микрокремнезёма и суперпластификатора на свойства бетона / С.С. Каприелов, А.В. Шейнфельд, Ю.Р. Кривобородов // Бетон и железобетон. - 1992. - №7. - С. 4-7.

10. Каприелов, С.С. Модифицированные высокопрочные бетоны классов В80 и В90 в монолитных конструкциях / С.С. Каприелов, В.И. Травуш, Н.И. Карпенко [и др.] // Строительные материалы. - 2008. - № 3. - С. 9-13.

11. Соломатов, В.И. Гидратация и структурообразование цементных композиций с известняковым и гранитным наполнителем / В.И. Соломатов, Гбего Тосса Аогнибо Жильбер, С.Н. Боровская // Научные исследования и их внедрение в строительной отрасли. - Саранск, 1989. - С. 23-24.

12. Баженов Ю.М. Технология бетона: учебник / Ю.М. Баженов. - М.: АСВ, 2007. - 528 с.

13. Волженский, A.В. Применение зол и топливных шлаков в производстве строительных материалов / А.В. Волженский, И.А. Иванов, Б.Н. Виноградов. - М.: Стройиздат, 1984. - 255 с.

14. Ахвердов, И.Н. Основы физики бетона / И.Н. Ахвердов. - М.: Стройиздат, 1981. - 464 С.

15. Чернышов E.M. Неоднородность структуры и сопротивление разрушению конгломератных строительных композитов: вопросы материаловедческого обобщения и развития теории / Е.М. Чернышов, Е.И. Дьяченко, А.И. Макеев. - Воронеж: ВГАСУ, 2012. - 97 с.

16. Прочность и параметры разрушения цементных композитов: монография / И.Н. Максимова, Н.И. Макридин, В.Т. Ерофеев [и др.]. - Саранск: Изд-во Мордов. ун-та, 2015. - 360 с.

17. Биологическое сопротивление материалов / В.И. Соломатов, В.Т. Ерофеев, В.Ф. Смирнов [и др.]. - Саранск: Изд-во Мордов. ун-та, 2001. - 194 С.

18. Ерофеев, В.Т. Биостойкость декоративных цементных композитов / В.Т. Ерофеев, А.И. Родин // Региональная архитектура и строительство. - 2013. - № 3. - С. 32-38.

19. Бажанова, М.Е. Стойкость трубопроводных материалов в условиях воздействия почвенных микроорганизмов / М.Е. Бажанова, В.Т. Ерофеев // Вестник Белгор. гос. технол. ун-та им. В. Г. Шухова. - 2012. - № 1. - С. 31-33.

20. Разработка способов повышения биостойкости строительных материалов / Б.В. Гусев, В.Т. Ерофеев, В.Ф. Смирнов 
[и др.] // Промышленное и гражданское строительство. 2012. - № 4. - C. 52-58.

21. Биокоррозия цементных бетонов, особенности еёразвития, оценки и прогнозирования / В.Т. Ерофеев, А.П. Федорцов, А.Д. Богатов [и др.] // Фундаментальные исследования. - 2014. - № 12. - С. 708-716.

22. Повышение биостойкости строительных материалов и изделий посредством пропитки их пористой структуры / В.Т. Ерофеев, В.Ф. Смирнов, А.В. Дергунова [и др.] // Известия КазГАСУ. - 2010. - № 2 (14). - С. 218-222.

23. Видовой состав микофлоры, выделенной с полимерных композитов на основе эпоксидных смол в условиях влажного морского климата / В.Т. Ерофеев, А.В. Лазарев, А.Д. Богатов [и др.] // Известия КазГАСУ. - 2013. - № 2 (24).- С. 233-237.

24. Розенталь, Н.К. Вопросы коррозионной стойкости бетона при воздействии биологических активных сред / В.К. Розенталь, Г.В. Чехний // Бетон и железобетон - взгляд в будущее. В 7 т. - М., 2014. - Т. 3. - С. 367-376.

25. Розенталь, Н.К. Коррозия цементных материалов, вызванная воздействием грибков \Н.К. Розенталь, Г.В. Чехний, А.И. Мельникова // Бетон и железобетон. - 2000. - № 6. - С. 23-26.

26. Sorensen, T.A. method of establishing groups of equal amplitude in plant sociology based on similarity of species content // Kongelige Danske Videnskabemes Selskab. Biol. krifter. Bd V. № 4. 1948. P. 1-34.

\section{Literatura}

1. Kalashnikov V.I. Kak prevratit' betony starogo pokoleniya v vysokoeffektivnye betony novogo pokoleniya / V. I. Kalashnikov // Beton i zhelezobeton. - 2012. - № 1. - S. 82-89.

2. Bobryshev A.N. Fizika i sinergetika dispersnoneuporyadochennyh kondensirovannyh kompozitnyh sistem / A.N. Bobryshev, V. T. Erofeev, V.N. Kozomazov. - SPb. : Nauka, 2012. - $476 \mathrm{~s}$.

3. Kalashnikov V.I. Chto takoe poroshkovo-aktivirovannyj beton novogo pokoleniya / V.I. Kalashnikov // Stroitel'nye materialy. - 2012. - № 10. - S. 70-71.

4. Nanogidrosilikatnye tehnologii v proizvodstve betonov / V.I. Kalashnikov, V.T. Erofeev, M.N. Moroz [i dr.] // Stroitel'nye materialy. - 2014. - № 5. - S. 88-91.

5. Kalashnikov V.I. Suspenzionno-napolnennye betonnye smesi dlya poroshkovo-aktivirovannyh betonov novogo pokoleniya / V.I. Kalashnikov, V.T. Erofeev, 0.V. Tarakanov // Izvestiya vuzov. Seriya «Stroitel'stvo». - 2016. - № 4 (688). - S. 30-37.

6. Kalashnikov V.I. Vysokoprochnye betony novogo pokoleniya / V.I. Kalashnikov, I.V. Erofeeva // Science without borders. - 2016. - Vol. 20. - P. 82-85.

7. Kalashnikov V.I. Vysokoprochnye betony novogo pokoleniya s nizkim udel'nym raskhodom tsementa na edinitsu prochnosti / V.I. Kalashnikov, V. M. Volodin, I.V. Erofeeva // Vedecky pokrok na prelomu tysyachalety. - 2015. - P. 65-67.

8. Rol' dispersnosti i kachestva kvartsevogo peska na reologiyu i prochnostnye svojstva suspenzionnogo betona / S.V.
Anan'ev, S.V. Aksenov, I.V. Erofeeva [i dr.] // Nauka i inowacja. - 2014. - Vol. 10. - P. 40-44.

9. Kaprielov S.S. Vliyanie struktury tsementnogo kamnya s dobavkami mikrokremnezema i superplastifikatora na svojstva betona / S.S. Kaprielov, A.B. Shejnfel'd, Yu.R. Krivoborodov // Beton i zhelezobeton. - 1992. - №7. - S. 4-7.

10. Kaprielov S.S. Modifitsirovannye vysokoprochnye betony klassov V80 i V90 v monolitnyh konstruktsiyah / S.S. Kaprielov, V.I. Travush, N.I. Karpenko [i dr.] // Stroitel'nye materialy. 2008. - № 3. - S. 9-13.

11. Solomatov V.I. Gidratatsiya i strukturoobrazovanie tsementnyh kompozitsij s izvestnyakovym i granitnym napolnitelem / V.I. Solomatov, Gbego Tossa Aognibo Zhil'ber, S.N. Borovskaya // Nauchnye issledovaniya i ih vnedrenie $v$ stroitel'noj otrasli. - Saransk, 1989. - S. 23-24.

12. Bazhenov Yu.M. Tehnologiya betona: uchebnik / Yu.M. Bazhenov. - M.: ASV, 2007. - 528 s.

13. Volzhenskij A.V. Primenenie zol i toplivnyh shlakov v proizvodstve stroitel'nyh materialov / A.V. Volzhenskij, I.A. Ivanov, B.N. Vinogradov. - M.: Strojizdat, 1984.- 255 s.

14. Ahverdov I.N. Osnovy fiziki betona / I.N. Ahverdov. - M.: Strojizdat, 1981. - $464 \mathrm{~s}$.

15. Chernyshov E.M. Neodnorodnost' struktury i soprotivlenie razrusheniyu konglomeratnyh stroitel'nyh kompozitov: voprosy materialo-vedcheskogo obobshheniya i razvitiya teorii / E.M. Chernyshov, E.I. D'yachenko, A. I. Makeev. - Voronezh: VGASU, 2012. - $97 \mathrm{~s}$.

16. Prochnost' i parametry razrusheniya tsementnyh kompozitov: monografiya / I.N. Maksimova, N.I. Makridin, V.T. Erofeev [i dr.]. Saransk: Izd-vo Mordov. un-ta, 2015. - 360 s.

17. Biologicheskoe soprotivlenie materialov / V.I. Solomatov, V.T. Erofeev, V.F. Smirnov [i dr.]. - Saransk: Izd-vo Mordov. unta, 2001. - $194 \mathrm{~s}$.

18. Erofeev V.T. Biostojkost' dekorativnyh tsementnyh kompozitov / V.T. Erofeev, A.I. Rodin // Regional'naya arhitektura i stroitel'stvo. - 2013. - № 3. - S. 32-38.

19. Bazhanova M.E. Stojkost' truboprovodnyh materialov $v$ usloviyah vozdejstviya pochvennyh mikroorganizmov / M.E. Bazhanova, V.T. Erofeev // Vestnik Belgor. gos. tehnol. un-ta im. V.G. Shuhova. - 2012. - № 1. - S. 31-33.

20. Razrabotka sposobov povysheniya biostojkosti stroitel'nyh materialov / B.V. Gusev, V.T. Erofeev, V.F. Smirnov [i dr.] // Promyshlennoei grazhdanskoe stroitel'stvo. -2012. - № 4. -S. 52-58.

21. Biokorroziya tsementnyh betonov, osobennosti ee razvitiya, otsenki i prognozirovaniya / V.T. Erofeev, A.P. Fedortsov, A.D. Bogatov [i dr.] // Fundamental'nye issledovaniya/ - 2014. - № 12. - S. 708-716.

22. Povyshenie biostojkosti stroitel'nyh materialov $\mathrm{i}$ izdelij posredstvom propitki ih poristoj struktury / V.T. Erofeev, V.F. Smirnov, A.V. Dergunova [i dr.] // Izvestiya KazGASU. - 2010. - № 2 (14). - S. 218-222.

23. Vidovoj sostav mikoflory, vydelennoj s polimernyh kompozitov na osnove epoksidnyh smol v usloviyah vlazhnogo 
morskogo klimata / V.T. Erofeev, A.V. Lazarev, A.D. Bogatov [i dr.] // Izvestiya KazGASU. - 2013. - № 2 (24). - S. 233-237.

24. Rozental' N.K. Voprosy korrozionnoj stojkosti betona pri vozdejstvii biologicheskih aktivnyh sred / V.K. Rozental', G.V. Chehnij // Beton i zhelezobeton - vzglyad v budushhee: $v 7$ t. - M., 2014. - T. 3. - S. 367-376.
25. Rozental' N.K. Korroziya tsementnyh materialov, vyzvannaya vozdejstviem gribkov \N.K. Rozental', G.V. Chehnij, A.I. Mel'nikova // Beton i zhelezobeton. - 2000. № 6. - S. 23-26.

Ерофеев Владимир Трофимович, 1954 г.р. (Саранск). Доктор технических наук, профессор, академик РААСН. Заведующий кафедрой строительных материалов и технологий, декан архитектурно-строительного факультета ФГБОУ В0 «МГУ им. Н.П. Огарёва» (430000, г. Саранск, Советская, 24). Сфера научных интересов: исследования в области композиционных строительных материалов и ресурсосберегающих технологий, биологического сопротивления и долговечности материалов и изделий, безопасности зданий и сооружений. Автор более 1000 научных работ и публикаций. Тел.: 8 (8342) 47-40-19. E-mail: AL_Rodin@mail.ru.

Каблов Евгений Николаевич, 1952 г.р. (Москва). Доктор технических наук, профессор, академик РАН. Генеральный директор ФГУП ГНЦ РФ «Всероссийский научно-исследовательский институт авиационных материалов» (105005, Москва, ул. Радио, 17. ВИАМ). Сфера научных интересов: научные и технологические основы получения полимерных и металлических композиционных материалов, интерметаллидных и других сплавов. Автор более 1000 научных работ и публикаций. Тел.: 8 (499) 261-86-77, 8 (499) 267-86-09. E-mail: admin@viam.ru

Старцев Олег Владимирович, 1949 г.р. (Геленджик). Доктор технических наук, профессор. Заместитель начальника по научной работе филиала ФГУП ГНЦ РФ «Всероссийский институт авиационных материалов» Геленджикского центра климатических испытаний им Г.В. Акимова (353475, Россия, Краснодарский край, Геленджик, ул. Почтовая, 20. ГЦкИ ВИАМ). Сфера научных интересов: полимерные композиционные материалы, прогнозирование свойств при климатическом старении, процессы влагопереноса, динамический механический анализ. Автор более 350 научных и учебно-методических работ, в том числе 5 монографий и справочников, 14 авторских свидетельств на изобретения и патентов РФ. Тел.: +7 (86141)-2-82-26.E-mail: startsevov@gmail.com.

Смирнов Василий Филиппович, 1952 г.р. (Нижний Новгород). Доктор биологических наук, профессор. Заведующий отделом химико-биологических исследований НИИ химии ФГАОУ ВО «Нижегородский государственный университет им. Н.И. Лобачевского» (603950, ГСП 43, Н. Новгород, пр. Гагарина 23, ГУ им. Н.И. Лобачевского, корп. 5. НИИ химии ННгУ). Сфера научных интересов: исследования фундаментальных и прикладных аспектов проблемы биоповреждений материалов и изделий, поиск эффективных средств и способов зашиты от биоповреждений. Автор более 500 научных работ и публикаций. Тел.: 8 (831) 417-05-93. E-mail: biodeg@mail.ru.

Ерофеева Ирина Владимировна (Саранск). Младший научный сотрудник ФГБУ «Научно-исследовательский институт строительной физики российской академии архитектуры и строительных наук» (127238, Москва, Локомотивный проезд, 21. НИИСФ РААСН). Сфера научных интересов: общественные пространства для искусства на примере немецких городов, архитектурно-строительное материаловедение. Автор 30 научных публикаций. Тел.: +7 (927) 276-96-75. E-mail: erofeeva. ira2014@yandex.ru.

Ушкина Виктория Валентиновна (Саранск). Кандидат технических наук. Учитель первой квалификационной категории ГБоУ РМ «Республиканский лицей» (430005, Саранск, ул. Московская, 46). Сфера научных интересов: биологические технологии в производстве модификаторов бетонов, разработка пенобетонов теплоизоляционного и теплоизоляционно-конструкционного назначения, биологическая стойкость и биологическое обрастание строительных материалов. Автор 12 публикаций, включая 1 патент на изобретение. Тел.: +7 (902) 234-30-37. E-mail: ntaevv@mail.ru.

Емельянов Денис Владимирович, 1983 г.р. (Саранск). Кандидат технических наук. Доцент кафедры строительных материалов и технологий архитектурно-строительного факультета ФГБОУ В0 «МГУ им. Н.П. Огарёва» (430000, г. Саранск, Советская, 24). Сфера научных интересов: цементные композиционные материалы на основе активированной воды затворения, порошковоактивированные самоуплотняющиеся бетоны, биостойкие цементные композиционные материалы. Автор более 60 научных работ, в том числе 3 патентов и 1 монографии. Тел.: +7 (909) 325-93-97. E-mail: emelyanoffdv@yandex.ru. 
Балатханова Элита Махмудовна (Аргун). Кандидат технических наук. Доцент кафедры прикладной механики и инженерной графики ФГБоУ В0 «ГГНТУ им. акад. Миллионщикова» (364051, Чеченская Республика, Грозный, пр. им. Х.А. Исаева, 100). Сфера научных интересов: композиционные строительные материалы повышенной биостойкости с применением сырьевых компонентов, добываемых в Чеченской республике. Автор 37 научных и учебно-методических работ и 1 свидетельства на изобретение. Тел.: +7 (962) 654-23-79. E-mail: elita.74@mail.ru.

Коротаев Сергей Александрович, 1957 г.р. (Саранск). Кандидат технических наук, доцент. Доцент кафедры зданий, сооружений и автомобильных дорог архитектурно-строительного факультета ФГБОУ В0 «МГУ им. Н.П. Огарёва»(430000, Саранск, Советская, 24). Сфера научных интересов: исследования в области технологии и свойств строительных материалов и изделий; оценка микроклимата зданий. Автор более 80 научных работ, в том числе 6 авторских свидетельств на изобретения. Тел.: +7 (903) 051-15-32. E-mail: korotaevc@yandex.ru.

Erofeev Vladimir Trofimovich, born in 1954 (Saransk). Doctor of technical sciences, professor, academician of RAASN. Head of the Department of Building Materials and Technologies, Dean of the Faculty of Architecture and Civil Engineering of the Federal state budgetary academic institution of higher education "N.P.Ogarev Mordovia State University" (430000, Saransk, Sovetskaya, 24, 0garev Mordovia State University). Sphere of scientific interests: research in the field of composite building materials and resource-saving technologies, biological resistance and durability of materials and products, safety of buildings and structures. Author of more than 1000 scientific publications and publications. Phone: 8 (8342) 47-40-19. E-mail: AL_Rodin@mail.ru.

Kablov Evgeniy Nikolaevich, born in 1952 (Moscow). Doctor of technical sciences, professor, academician of RAS. General director Federal State Unitary Enterprise "All-Russian Scientific Research Institute of Aviation Materials" (105005, Moscow, st. Radio, 17. VIAM). Sphere of scientific interests: scientific and technological foundations for the production of polymeric and metallic composite materials, intermetallic and other alloys. Author of more than 1000 scientific publications. Phone: +7 (499) 261-8677, +7 (499) 267-86-09. E-mail: admin@viam.ru.

Startsev Oleg Vladimirovich, born in 1949 (Gelendzhik). Doctor of technical sciences, professor. Deputy Chief of the Scientific Work of the branch of FSUE "All-Russian Institute of Aviation Materials" - Gelendzhik Climate Test Center named after G.V. Akimova (353475, Russia, Krasnodar Territory, Gelendzhik, st. Pochtovaya, 20). Sphere of scientific interests: polymeric composite materials, prediction of properties under climatic aging, moisture transfer processes, dynamic mechanical analysis. Author of more than 350 scientific and educational-methodical works, including 5 monographs and reference books, 14 copyright certificates for inventions and patents of the Russian Federation. Phone: +7 (86141) 2-82-26. E-mail: startsevov@gmail.com.

Smirnov Vasily Filippovich, born in 1952 (Nizhny Novgorod). Doctor of biological sciences, professor. Head of the Department of Chemical and Biological Research, Institute of Chemistry, FGAOU V0 "Nizhny Novgorod State University N.I. Lobachevsky" (603950, GSP 43, N. Novgorod, Gagarin Ave. 23. UNN). Scientific interests: research of fundamental and applied aspects of the problem of biodeterioration of materials and products, search for effective means and methods of protection from bodily harm. Author of more than 500 scientific publications. Phone: +7 (831) 417-05-93. E-mail: biodeg@mail.ru

Erofeeva Irina Vladimirovna (Saransk). Junior researcher of FGBU "Research Institute of Building Physics of the Russian Academy of Architecture and Building Sciences" (127238, Moscow, Locomotivny passage, 21). Sphere of scientific interests: public spaces for art on the example of German cities, architectural and construction materials. Author of 30 scientific publications. Phone: +7 (927) 276-96-75.E-mail: erofeeva.ira2014@yandex.ru.

Ushkina Victoria Valentinovna (Saransk). Candidate of technical sciences. Teacher of the first qualification category of GBOU RM "Republican Lyceum" (430005, Republic of Mordovia, Saransk, st. Moscovskaya, 46. Republican Lyceum). Sphere of scientific interests: biological technologies in the production of concrete modifiers, development of foam concrete heat-insulating and heat-insulating-structural purpose, biological stability and biological fouling of building materials. Phone: + 7 (902) 234-30-37. E-mail: ntaevv@mail.ru. Author of 12 publications, including 1 patent for invention.

Emelyanov Denis Vladimirovich, born in 1983 (Saransk). Candidate of technical sciences. Associate professor of the Department of Building Materials and Technologies of the Faculty of Architecture and Civil Engineering of the Federal state budgetary academic institution of higher education "N.P. Ogarev Mordovia State University" (430000, Saransk, Sovetskaya, 24. Ogarev Mordovia State University). Sphere of scientific interests: cement composite materials based on activated mixing water, powder-activated self- 
compacting concretes, biostable cement composite materials. Author of more than 60 scientific papers, including 3 patents and 1 monograph. Phone: +7 (909) 325-93-97.E-mail: emelyanoffdv@yandex.ru.

Balatkhanova Elita Mahmudovna (Argun). Candidate of technical sciences. Associate professor of the Department of Applied Mechanics and Engineering Graphics of the "Grozny State Technical University of Petroleum named after Academician M.D. Millionshchikov" (364051, Grozny, Avenue of the name of Kh.A. Isaeva, 100). Sphere of scientific interests: composite building materials of increased biostability with the use of raw materials extracted in the Chechen Republic. Author of 37 scientific and educational-methodical works and 1 certificate for invention. Phone: +7 (962) 654-23-79. E-mail: elita.74@mail.ru.

Korotaev Sergey Alexandrovich, born in 1957 (Saransk). Candidate of technical sciences, associate professor. Associate professor of the Department of Buildings, Structures and Highways of the Faculty of Architecture and Civil Engineering of the Federal state budgetary academic institution of higher education "N.P. Ogarev Mordovia State University" (430000, Saransk, Sovetskaya, 24. Ogarev Mordovia State University). Sphere of scientific interests: research in the field of technology and properties of building materials and products; assessment of the microclimate of buildings. Author of more than 80 scientific works, including 6 copyright certificates for inventions. Phone: 7 (903) 051-15-32. E-mail: korotaevc@yandex.ru. 